\title{
SOME ASPECTS OF THE PERFORMANCE OF 'GRASSLANDS PAWERA' RED CLOVER IN SOUTHLAND
}

\author{
R. J. M. Hay', R. W. Kelly', D. L. RyaN
}

Abstract

Grazing experiments investigating some factors determining the dry matter production and oestrogenicity of Pawera red clover are described. The legume content of the summer dry matter yield was double that of Ruanui and Huia pasture following overdrilling of lightly paraquated pasture with 4 or $8 \mathrm{~kg} / \mathrm{ha}$ of Pawera. Persistence of Pawera was demonstrated by its ability to survive in sufficient density under grazing to contribute $35 \%$ of total summer dry matter production in its fourth year after direct drilling into lightly paraquated pasture. A Pawera sward when overdrilled with Tama ryegrass or Rahu ryecorn produced the same annual yield as Ariki/ Huia pasture, but the seasonal distribution was markedly different, with production from the overdrilled Pawera being greater in winter and summer. Pure Pawera swards produced some $70 \%$ more dry matter during December-February than Ariki/Huia pasture. The significance of this is related to conservation practices in Southland. Oestrogenicity of pure swards of Pawera was determined by measuring the cervical mucus response in ovariectomized ewes. Responses to grazing were equivalent to a single injection of 9 to $31 \mu \mathrm{g}$ of oestradiol-17ß.

\section{INTRODUCTION}

TETRAPLOID red clovers have shown greater productivity and persistence (Julén, 1956) and disease resistance (Vestad, 1960) than diploid red clovers. Consequently Grasslands Division embarked on a breeding programme leading to the release of 'Grasslands Pawera' tetraploid red clover (Trifolium pratense L.). Development was by selection and breeding after colchicine treatment of 'Grasslands Turoa' and some lines introduced from Sweden (Anderson, 1973a).

In a mowing trial at Palmerston North, Pawera gave higher yields, particularly in the summer and autumn, than 5 diploid red clovers and white clover, and was the most persistent red clover (Anderson, 1973b). Harris et al. (1973) found in Southland that ' $G$ 4706' (later released as Pawera) outyielded 3

${ }_{1}$ Grasslands Division, DSIR, Private Bag, Gore.

2 Invermay Agricultural Research Centre, Private Bag, Mosgiel. 
diploid varieties at two cutting regimes, $23 \mathrm{~cm}$ to $5 \mathrm{~cm}$ and $10 \mathrm{~cm}$ to $2 \mathrm{~cm}$, while at Lincoln E. W. Vartha (pers. comm.) recorded yields in excess of $20000 \mathrm{~kg} / \mathrm{ha}$ dry matter (DM) from ' $G$ 4706' under a lax cutting system during the 1960-1 season. Also in a mowing trial on a dryland site in the Waitaki Valley, Sheath et al. (1976) showed production from Pawera to be superior to Turoa in spring and summer but not in autumn. Because these trials and many others in progress were under cutting, and there has been no work on possible oestrogenic effects of Pawera to sheep, production and oestrogenicity of Pawera under grazing were investigated.

\section{EXPERIMENTAL METHODS}

The first 'experiment commenced in spring 1973 by direct drilling Pawera at two sowing rates (4 and $8 \mathrm{~kg} / \mathrm{ha}$ ), and Ruanui (Lolium perenne L.) and Nui (L. perenne L.) ryegrasses at $15 \mathrm{~kg} / \mathrm{ha}$, with a triple-disc "730 Multiliner" drill into "runout" pasture which had been sprayed at the light rate of $360 \mathrm{~g}$ active ingredient paraquat/ha. This spraying treatment was designed to remove all grass apart from ryegrass which demonstrates a resistence to this rate of paraquat. Treatments were grazed with wethers to $2 \mathrm{~cm}$ when the regrowth height averaged $15 \mathrm{~cm}$. In- the second experiment, which commenced in spring 1974, the seasonal production of pure Pawera swards and Pawera overdrilled with the winter annuals 'Grasslands Tama' Westerwolds (Lolium multiflorum Lam.) and Rahu ryecorn (Secale cereale L.) were compared with a pasture comprising 'Grasslands Ariki' ryegrass/'Grasslands Huia' white clover (Lolium ((perenne $X$ multiflorum) $x$ perenne) and Trifolium repens L.) . A frequent $(15 \mathrm{~cm}$ to $4 \mathrm{~cm})$ and infrequent $(23 \mathrm{~cm}$ to $4 \mathrm{~cm}$ ) grazing regime was applied to each treatment over the spring-summer months. In both trials four $0.25 \mathrm{~m}^{2}$ quadrats per plot were harvested using hand shears immediately before grazing. Stocking rate was adjusted to achieve defoliation to the required height in less than 48 hours. If necessary paddocks were topped after grazing. Both experiments had four replications. Each autumn $375 \mathrm{~kg} / \mathrm{ha}$ of $25 \%$ potassic superphosphate (O-7-12) was applied to both experiments.

Oestrogenic activity of Pawera to sheep was investigated in 1977, using the oestrogen bioassay production of cervical mucus in ovariectomized Romney ewes (Lindsay and Francis, 1968). The response after 3 days' grazing was calculated, in equivalents of oestradiol-17 $\beta$, using a dose response curve from control ewes 
TABLE 1: MEAN HERBAGE YIELD ( $\mathrm{kg}$ DM/ha) FROM OVERDRILLED PASTURE, 1974-5 AND 1975-6

\begin{tabular}{|c|c|c|c|c|c|c|c|}
\hline \multirow{3}{*}{$\frac{\text { Species }}{\text { Pawera }}$} & \multirow{2}{*}{$\begin{array}{c}\begin{array}{c}\text { Sowing } \\
\text { Rate } \\
\text { (kg/ha) }\end{array} \\
48\end{array}$} & \multicolumn{2}{|c|}{$\begin{array}{r}\text { Summe } \\
\text { Clover } \\
\text { Pawera White }\end{array}$} & \multirow{2}{*}{$\frac{\text { All spp. }}{4500}$} & \multicolumn{3}{|c|}{$\begin{array}{l}\text { Remainder of Annual } \\
\text { Production } \\
\text { Clover } \\
\text { Pawera White All spp. }\end{array}$} \\
\hline & & 1380 & 820 & & 610 & 1140 & 7700 \\
\hline & & 1440 & 810 & 4550 & 1070 & 1030 & 7550 \\
\hline Ruanui & 15 & & 900 & 3650 & & 1080 & 7700 \\
\hline Nui & 15 & & 1050 & 3800 & & 1000 & 8850 \\
\hline LSD $5 \%$ & & 270 & 410 & 850 & 350 & 490 & 1850 \\
\hline
\end{tabular}

*December 1-March 1 .

TABLE 2: DM PRODUCTION (kg/ha) FOR SUMMER PERIOD 1976-7 (NOVEMBER PO-MARCH 10) FOUR YEARS AFTER DRILLING

\begin{tabular}{lcccccc}
\hline $\begin{array}{l}\text { Overdrilled } \\
\text { and Sowing Rate }\end{array}$ & $\begin{array}{c}\text { Species } \\
\text { Pawera }\end{array}$ & $\begin{array}{c}\text { White } \\
\text { Clover }\end{array}$ & R yegrass & $\begin{array}{l}\text { Other Species } \\
\text { \& Dead Matter }\end{array}$ & Total \\
\hline $\begin{array}{l}\text { Pawera } 8 \mathrm{~kg} / \mathrm{ha} \\
\text { \% of total }\end{array}$ & 1920 & 660 & 1540 & 1440 & 5560 \\
\hline
\end{tabular}

TABLE 3: MEAN SEASQNAL DISTRIBUTION OF PRODUCTION (kg DM/ha) FROM 1974-5 AND 1975-6 WITH . FREQUENT OR INFREQUENT DEFOLIATION

\begin{tabular}{lccccr}
\hline \multicolumn{1}{c}{ Swards } & Spring* & Summer & A u'tumn & Winter & Total \\
\hline Pawera & 4500 & 7100 & 1200 & 750 & 13550 \\
Pawera +, winter annual. & 6000 & 5000 & 1500 & 2000 & 14500 \\
Ariki/Huia pasture & 6600 & 4100 & 2500 & 1200 & 14400 \\
LSD 5\% & 640 & 760 & 390 & 390 & 890
\end{tabular}

*Spring period taken as September-November inclusive.

TABLE 4: OESTROGENIC ACTIVITY OF PAWERA TO OVARIECTOMIZED EWES AND LEAF FORMONONETIN CONCENTRATION

\begin{tabular}{|c|c|c|c|c|}
\hline $\begin{array}{l}\text { Time } \\
\text { of Grazing }\end{array}$ & \multicolumn{2}{|c|}{$\begin{array}{l}\text { Mean Mucus } \\
\text { Production (g) } \\
\text { Control Pawera } \\
\text { Ew es Fed Ewes }\end{array}$} & $\begin{array}{l}\text { Response in } \\
\text { Equivalents of } \\
O D-17 \beta(\mu g)\end{array}$ & \multirow{2}{*}{$\begin{array}{c}\begin{array}{c}\text { Formononetin } \\
(\% \mathbf{D M})\end{array} \\
0.63\end{array}$} \\
\hline Late January & 0.24 & 0.91 & 15 & \\
\hline Early March & 0.17 & 1.52 & 31 & 1.39 \\
\hline Early May & 0.32 & 1.08 & 9 & 0.84 \\
\hline
\end{tabular}


grazing ryegrass/white clover pasture. In addition, the amount of formononetin in the leaves of the Pawera at the time of grazing was determined by the technique of Francis and Millington (1965).

\section{RESULTS}

\section{YIELD}

'Table 1 presents DM production obtained in the first experiment from two drilling rates of Pawera and compares it with Ruanui and Nui.

These figures show marked differences in the legume component of the yields. Clover production in the Pawera treatments was superior to that from the Nui and Ruanui plots at all times, and contributed up to half the total summer production. This superiority in summer was due principally to production from Pawera. The contribution was evenly shared by Pawera and white clover during the remainder of the year in the. $8 \mathrm{~kg} / \mathrm{ha}$ Pawera treatment. There was no evidence of suppression of white clover in the plots overdrilled with Pawera.

The persistence of Pawera was demonstrated by the Pawera in the overdrilled plots still producing $35 \%$ of the total DM in the fourth summer after sowing (Table 2).

Another measure of the persistence of Pawera was made in the same experiment by counting plants present in random quadrats within the plot. Over the $31 / 2$-year period, the numbers declined rapidly in the first 18 months, but thereafter showed little change (Fig. 1).

Pawera overdrilled with Tama or Rahu ryecom gave similar total yields to Ariki/Huia pasture but out-produced it in summer and winter (Table 3). Pure Pawera swards produced $3000 \mathrm{~kg}$ / ha more than pasture over the summer period but less in other seasons.

\section{Oestrogenic EFFects}

Stands of pure Pawera grazed three times in the summerautumn period resulted in the secretion of large amounts of cer: vical mucus by ovariectomized ewes - more than that produced by ewes grazing non-oestrogenic pastures (Table 4). The responses were equivalent to that produced following single injection of between 9 and $31 \mu \mathrm{g}$ of oestradiol-17 $\beta$. Concentration of formononetin in Pawera was high at all times. 




Fig. 1: Persistence of Pawera drilled at two rates.

\section{DISCUSSION}

The Ruanui and Nui plots confirm work of Harris et al. (1973) and Radcliffe (1974) which has shown that the percentage legume in Southland pastures in low compared with other regions in New Zealand (Brougham, 1960; Radcliffe, 1975a, b; Radcliffe and Sinclair, 1975; Baars et al., 1975). This low legume content and poor pasture growth in the late summer-autumn period causes problems on many Southland farms, in getting lambs to killing weight before there is competition for feed for flushing ewes prior to tupping. Pawera could be used in combination with grasses to provide special pastures for finishing lambs in late summer. This would utilize the higher nutritive value of legumedominant pasture (Ulyatt et al., 1976) and the greater production of Pawera in late summer. The writers consider a red clover population of about 12 plants $/ \mathrm{m}^{2}$ in a mixed sward was sufficient to give high quality production without penalizing autumn grass growth. Figure 1 shows that a stable population of this value could be achieved by overdrilling at $4 \mathrm{~kg} / \mathrm{ha}$. It was sufficient to contribute $35 \%$ of the DM production during the summer of the fourth year (Table 2). 
An important feature of Pawera is its compatibility with a winter annual, introduced by overdrilling following hard grazing. This gives better spread of production throughout the year than either a conventional white clover-based pasture or pure Pawera. The overdrilling technique will give more feed in late winterearly spring.

The phyto-oestrogen' formononetin, present 'in high concentrations in Pawera, has been found to cause infertility problems in sheep (Lindsay and Kelly, 1970). In Western Australia exposure of breeding ewes to pastures dominated by subterranean clover, later found to have high levels of formononetin, has resulted in lambing percentages (lambs tailed/ewes mated) falling from $80 \%$ to below $30 \%$ and with as many as $70 \%$ of the ewes exhibiting signs of permanent infertility (Bennetts et al., 1946). However, when the oestrogenic legume was mixed with a grass in pastures, the subsequent dilution of total ingested formononetin resuited in a lessening of deleterious effects (Davies and Maller, 1970).

It is concluded that it would be unwise to graze ewes for extended periods on pure Pawera, particularly at mating time, but the high late-summer production and excellent herbage quality of pure Pawera stands ( $23 \%$ crude protein) would be valuable for lamb finishing. Also, with Pawera's high yield potential during December to February, the hay-making period in 'Southland, hay requirements could be met with two or three cuts from a limited area. This hay may be fed to breeding stock, since drying to a moisture level suitable for conservation causes the formononetin level to decline markedly. For example, the writers have recorded formononetin levels falling from $1.0 \%$ at mowing to $0.2 \%$ at baling, a level considered by Marshall (1973) in his review to be unlikely to cause infertility in sheep.

Pawera appears therefore to have high potential in Southland, although indiscriminate use that disregards the important phytotoxic effects could lead to a decline in animal "production.

\section{ACKNOWLEDGEMENTS}

Mrs N. Heaps (nee Grace), Grasslands Division, Gore, for plant dissections and G. H. Shackell for technical assistance with cervical mucus determinations.

\section{REFERENCES}

Anderson, L. B., 1973a: N.Z. Jlagric. Res., 16: 395-8.

1973b: N.Z. $/ l$ exp. Agric., 1: 233-7.

Baars, J. A.; Radcliffe, J. E.; Brunswick, L., 1975: Ibid., 3: 253-8. 
Bennetts, H. W.; Underwood, E. J.; Shier, F. L., 1946: Aust. vet. J., 22: 2-12.

Brougham, R. W., 1960: N.Z. Il agric. Res., 3: 125-36.

Davies, H. L.; Maller, R. A., 1970: Proc. Amt. Soc. Anim. Prod., 8: 394- 9.

Francis, C. M.; Millington, A. J., 1965: Aust.J. agric. R es., 16: 557-64.

Harris, A. J.; Brown, K. R.; Turner, J. D.; Johnston, J. R.; Ryan, D. L.; Hickey, M. J., 1973: N.Z. Jl exp. A gric., 1: 139-63.

Julén, G., 1956: Proc. 7th int. G rassld Congr.: 471-8.

Lindsay, D. R.; Francis, C. M., 1968: Aust.J. agric. Res., 19: 1069-76.

Lindsay, D. R.; Kelly, R. W., 1970: Aust. vet. J., 46:219-22.

Marshall, T., 1973: Jl A gric. W. Aust., 14: 198-206.

Radcliffe, J. E., 1974: N.Z. Jl exp. A gric., 2: 341-8.

$$
\text { 1975a: Ibid., 3: 239-46. }
$$

Radcliffe, J. E.; Sinclair, D. P., 1975: Ibid., 3: 247-51.

Sheath, G. W.; Galletly, W. S.; Greenwood, P., 1976: Proc. N.Z. G rassId Ass., 38: $140-50$

Ulyatt, M. J.; Lancashire, J. A.; Jones, W. T., 1976: Proc. N.Z. GrassId Ass., 38: 107-18.

Vestad, R., 1960: Euphytica, 9: 35-8. 